\title{
ANALISIS EKSPERIMENTAL GAYA DAN TEGANGAN MATERIAL KOMPOSIT PADA PERANCANGAN PELINDUNG DADA PENGENDARA SEPEDA MOTOR
}

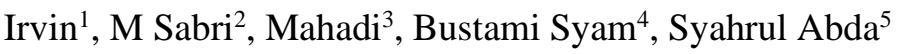 \\ Departemen Teknik Mesin, Fakultas Teknik Universitas Sumatera Utara \\ Email: Irviinblaze@gmail.com
}

\begin{abstract}
The goal of this research is to identify the stress and force that occur in the motorbike body protector which created using composite material in order to protect human chest. Free-fall drop test is done using Multifunctional Free-fall impact test tools. Specimen placed to the test rig which has adjustable drop height. The fall time of test is calculated using 8 inductive proximity sensors. It will fall and crashed the anvil. Impact force that occurs by the drop is measured using a load cell that placed under the anvil. Measurement data will transfer to analog device that changed the analog signal into a digital signal. Result data is saved in the PC as a table of force $(\mathrm{F})$ and time (t). Experimental test data for the body protector specimens using GFRP at the impactor height $3 \mathrm{~m}$ is $698.17 \mathrm{kgf}$ and stress $0.014 \mathrm{MPa}$. After the result compared with the computational result the mean transmission impact force is 14.95 $\mathrm{kN}$ and the maximum transmission impact force is $29.18 \mathrm{kN}$. Thus the transmission force that occur is not pass the European de Normalization (EN 1621-2) which for average impact force transmitted is $20 \mathrm{kN}$ and maximum impact force transmitted is $35 \mathrm{kN}$.
\end{abstract}

\section{Keyword : Free-fall Impact, Force Transmission, GFRP}

\section{PENDAHULUAN}

Pelindung dada merupakan alat pengaman berkendara yang berfungsi untuk menghindari melindungi bagian tubuh pengendara bila terjadi kecelakaan. Pelindung dada komposit ini selain dapat berfungsi menghalangi badan pengendara dari angin juga dirancang untuk menahan gesekan dan tumbukan yang terjadi ketika kecelakaan.

Pelindung dadaini dibuat dari bahan resin, serat kaca dan EVA foam (busa EVA). Bahanbahan ini dipilih karena mudah diperoleh di pasar dan mudah diproses serta ekonomis. Perpaduan resin dan serat kaca memiliki sifat keras yang dapat menahan gesekan yang terjadi ketika kecelakaan sepeda motor terjadi. Tetapi apabila di campur dengan resin dan serat kaca, pelindung dada ini akan bersifat kaku dan tidak dapat menahan efek gaya gunting. Untuk itu pada perancangan pelindung dada ini digunakan bahan tambahan berupa busa EVA agar lebih dapat menahan gaya gunting yang terjadi.

Tujuan dibuat pelindung dada ini adalah untuk melindungi pengendara sepeda motor ketika terjadi kecelakaan terutama untuk melindungi daerah dada pengendara. Dan ketika terjadi kecelakaan biasanya bagian dada kurang terlindung padahal bahaya yang timbul akibat benturan di dada berbahaya. Di dada terdapat banyak organ penting seperti paru-paru dan jantung yang perlu di lindungi.Yang lebih berbahaya lagi bila ulu hati terkena benturan. Untuk itu pelindung dada ini dirancang untuk menghalangi dua kejadian tersebut.

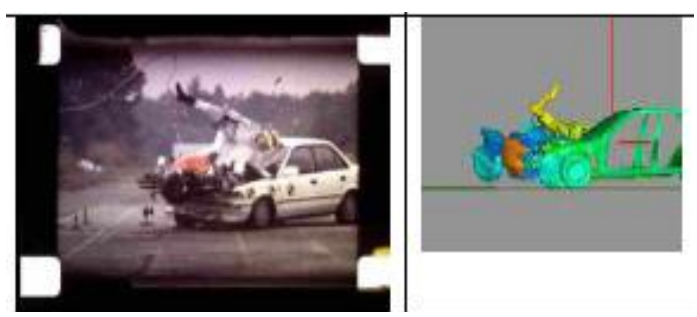

Gambar 1. Tabrakan sepeda motor dengan mobil pada sudut $90^{\circ}[1]$ 
Gambar 1 menunjukkan simulasi fenomena tabrakan antara pengendara sepeda motor dan mobil. Pada tabrakan ini bagian dada merupakan bagian yang dominan terkena benturan yang merupakan tujuan utama perlindungan pelindung dada yang kami rancang.

Contoh pelindung dada yang dijual dipasaran adalah pelindung dada dari LEATT Corporation. Pada desain produk ini pelindung dada dikonstruksi dengan lapisan multilayer, kerangka luar dijahit pada bagian dalam serta lapisan ditutupi dengan kain yang disambung dengan lapisan busa dan dilengkapi dengan bahan pengisi perforated. Standarisasi untuk produk ini sesuai EN(Europeen de Normalisation) 1621-3 dapat terlihat pada Tabel 1.

Tabel 1. Data Pengujian EN 1621-3 untuk Chest Protector LEATT [2]

\begin{tabular}{lcc}
\hline Gaya Impak Transmisi & Syarat EN 1621-3 & Pelindung Dada LEATT \\
\hline Mean kN & $<20$ & 12,1 \\
Max kN & $<35$ & 22,7 \\
\hline
\end{tabular}

Selain produk dari LEATT Corporation terdapat juga pelindung dada yang dibuat oleh Velocity Gear, LLC. Pada Produk ini perusahaan velocity gear juga menggunakan standarisasi EN 1621. Produk dari Velocity Gear telah diverikasi dengan bukti pengujian dan sertifikasi standar EN 1621-2 yang berupa "Pelat belakang dapat menyerap hingga 90\% dari energi dari 50KN dampak yang melebihi persyaratan EN 1621-2 untuk sepeda motor perlindungan Belakang" [3].

Untuk membuat hardshell pelindung dada pengendara sepeda motor pada penelitian ini digunakan bahan komposit. Komposit terdiri dari dua atau lebih komponen yang berbeda yang membentuk suatu kesatuan. Termasuk dalam kelompok ini: bahan yang diberi lapisan, bahan yang diperkuat dan kombinasi lain yang memanfaatkan sifat khusus beberapa bahan yang ada.

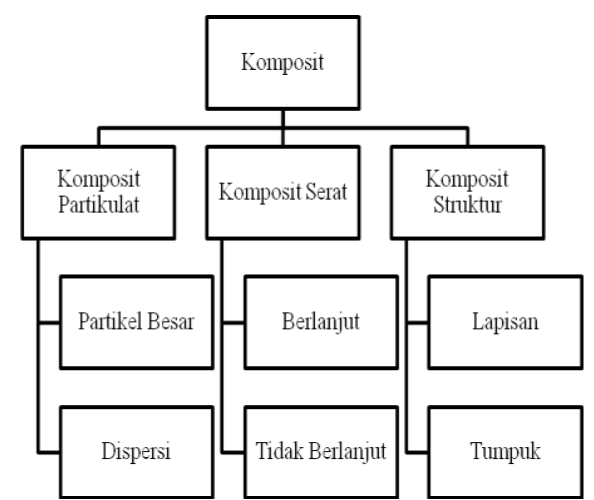

Gambar 2. Komposit berdasarkan jenis penguatnya [4]

Gambar 2 menunjukkan pembagian komposit berdasakan jenis penguatnya yaitu :

a. Komposit Partikulat (Particulate composite) adalah komposit dengan material penguatnya berbentuk partikel.

b. Komposit Serat (Fibre composite) adalah komposit dengan material penguatnya berbentuk serat.

c. Komposit Struktur (Structural composite) / struktur Laminat adalah komposit yang terdiri dari dua bahan yang berlainan (laminat).

Matrik dalam komposit berfungsi sebagai bahan mengikat serat menjadi sebuah unit struktur, melindungi dari perusakan eksternal, meneruskan atau memindahkan beban eksternal pada bidang geser antara serat dan matrik, sehingga matrik dan serat saling berhubungan [4].

Beberapa pakaian yang digunakan oleh pengendara bermotor jatuh pada category fashion dan tidak menyediakan fungsi perlindungan. Tetapi pakaian sepeda motor yang berada pada pasar Eropa memberikan fungsi perlindungan bagi penggunanya dari kecelakaan di awasi oleh Europa Directive.

Sekarang Eropa memimpin dalam mengatur standar keamanan untuk pakaian pelindung untuk pengendara sepeda motor. Terdapat komite teknis yang bekerja dalam naungan European standards body CEN (Comite Europeen de Normalisation) [5]. 
Pada perlindungan dari impak, standar Eropa yang digunakan adalah EN 1621. Standar ini terbagi atas beberapa bagian yang dikategorikan dari jenis bagian yang akan dilindungi.

Kategori standar perlindungan Impak EN 1621 adalah sebagai berikut:

1. EN 1621-1:2012

Untuk produk yang digunakan pada bagian sambungan badan.

2. EN 1621-2:2003

Untuk produk yang akan melindungi bagian belakang badan.

3. EN1621-3:2012

Untuk produk yang akan mellindungi bagian dada.

4. EN1621-42013

Untuk produk yang akan melindungi bagian perut.

Pada penentuan standarnya pengujian yang dilakukan untuk EN 1621 adalah merupakan uji impak yang anvil penghantamnya disesuaikan dengan bentuk produk.

Penentuan Level Proteksi EN 1621 adalah sebagai berikut:

1. Level 1: Rata-rata puncak Gaya Impak dibawah $30 \mathrm{kN}$ dan tidak ada nilai yang diatas $45 \mathrm{kN}$

2. Level 2: Rata-rata puncak Gaya Impak dibawah $20 \mathrm{kN}$ dan tidak ada nilai yang diatas $35 \mathrm{kN}$

Pada Penelitian ini material yang digunakan adalah Polymer Polyester, Busa EVA dan GFRP (Glass Fibre Reinforced Polymer) yang digabung dengan sistem sandwich. Pada tabel 2 dapat terlihat sifat mekanis dari material tersebut.

Tabel 2. Sifat Material Komposit [6][7]

\begin{tabular}{ccc}
\hline Nama & $\begin{array}{c}\text { Densitas } \\
\left(\mathrm{kg} / \mathrm{m}^{3}\right)\end{array}$ & $\begin{array}{c}\text { Modulus Elastisitas } \\
(\mathrm{GPa})\end{array}$ \\
\hline Material & $1004-1400$ & $2,07-4,41$ \\
Polyester Polymer & $945-955$ & $0,01-0,04$ \\
Busa EVA & $1350-1500$ & $6-12$ \\
GFRP & & \\
\hline
\end{tabular}

Menurut Robert (2007) hubungan antara gaya dengan jarak dengan menggunakan prinsip kekekalan energi kita dapat menghitung gaya impak teori yang terjadi. Usaha net yang terjadi selama impak sama dengan gaya impak rata-rata dikalikan dengan jarak yang dilalui setelah impak [8].

$$
\mathrm{W}_{\text {net }}=1 / 2 \mathrm{mv}_{\text {final }^{2}}{ }^{2}-1 / 2 \mathrm{mv}_{\text {initial }}{ }^{2}
$$

Pada aplikasi jatuh bebas, $\mathrm{W}_{\text {net }}=1 / 2 \mathrm{mv}_{\text {final }}{ }^{2}$ karena kecepatan awalnya adalah nol. Jadi untuk dapat menghitung jarak pantul setelah impak digunakan rumus:

$$
F=\frac{\text { Wnet }}{d} \quad d=\frac{\text { Wnet }}{F}
$$

Dimana:

$\mathrm{D} \quad=$ jarak pantul setelah impak

$\mathrm{F} \quad$ = gaya impak

$\mathrm{W}_{\text {net }} \quad=$ Usaha net yang terjadi selama impak 
Cara lain untuk mencari gaya impak yang terjadi adalah dengan menghubungkan antara gaya dengan waktu. Untuk cara ini digunakan hukum Newton kedua yaitu $\mathrm{F}=$ ma dimana a merupakan deselerasi yang terjadi untuk menghentikan gerakan spesimen.

Rumus untuk menghitung $a$ yang terjadi adalah:

$$
a=\frac{d v}{d t}=\frac{v_{\text {initial }}-v_{\text {final }}}{t_{\text {pulse }}}=2 \frac{\sqrt{2 g h}}{t_{\text {pulse }}}
$$

Dimana :

a $\quad=$ deselerasi akibat impak

$\mathrm{V} \quad=$ kecepatan

$\mathrm{t}_{\text {pulse }} \quad=$ waktu impak

$\mathrm{g} \quad=$ akselerasi akibat gravitasi

$h \quad=$ ketinggian jatuh

Setelah diperoleh deselerasi yang terjadi dapat diperoleh gaya impak berupa:

\section{METODOLOGI}

$$
F=m a=2 m \frac{\sqrt{2 g h}}{t_{\text {pulse }}}
$$

Penelitian ini dilaksanakan di Pusat Riset Impak dan Keretakan Jurusan Teknik Mesin Fakultas Teknik Universitas Sumatera Utara. Penelitian ini dimulai dengan pembuatan spesimen untuk pengujian impak jatuh bebas. Selanjutnya analisa data eksperimental menggunakan software DAQ For Helmet Impact Testing untuk mengolah data akusisi yang diperoleh dari Load cell.

Spesimen yang dibuat pada penelitian ini ada 4 material, yaitu Polyester Polymer, Glass Fibre Reinforced Polymer, Polyester Polymer Sandwich EVA Foam dan Glass Fibre Reinforced Polymer Sandwich EVA Foam. Komposisidari tiap material dapat terlihat pada tabel 3 berikut:

\begin{tabular}{|c|c|c|c|c|c|c|}
\hline \multirow{2}{*}{$\begin{array}{c}\text { Nama } \\
\text { Material }\end{array}$} & \multirow{2}{*}{$\begin{array}{c}\text { Nama } \\
\text { Spesimen }\end{array}$} & \multicolumn{4}{|c|}{ Komposisi ( $\%$ massa) } & \multirow{2}{*}{$\begin{array}{c}\text { Jenis } \\
\text { Material }\end{array}$} \\
\hline & & Resin & Katalis & Fibreglass & BusaEVA & \\
\hline \multirow{3}{*}{$\begin{array}{l}\text { Polyester } \\
\text { Polymer }\end{array}$} & Resin 1 & 97,5 & 2,5 & - & - & \multirow{3}{*}{ Polimer } \\
\hline & Resin 2 & 97,5 & 2,5 & - & - & \\
\hline & Resin 3 & 97,5 & 2,5 & . & - & \\
\hline \multirow{3}{*}{$\begin{array}{l}\text { Glass } \\
\text { Fibre } \\
\text { Reinforced } \\
\text { Polymer } \\
\text { (GFRP) }\end{array}$} & Fiber 1 & 77,6 & 2 & 20,4 & - & \multirow{3}{*}{$\begin{array}{c}\text { Komposi } \\
\text { Serat }\end{array}$} \\
\hline & Fiber 2 & 77,6 & 2 & 20,4 & - & \\
\hline & Fiber 3 & 77,6 & 2 & 20,4 & . & \\
\hline \multirow{3}{*}{$\begin{array}{l}\text { Polyester } \\
\text { Polymer } \\
\text { Sandwich } \\
\text { EVA foam }\end{array}$} & EVA Resin 1 & 90 & 2,2 & 8,8 & - & \multirow{3}{*}{$\begin{array}{l}\text { Komposi } \\
\text { Sandwich }\end{array}$} \\
\hline & EVA Resin 2 & 90 & 2,2 & 8,8 & - & \\
\hline & EVA Resin 3 & 90 & 2,2 & 8,8 & . & \\
\hline \multirow{3}{*}{$\begin{array}{c}\text { GFRP } \\
\text { Sandwich } \\
\text { EVA foam }\end{array}$} & EVAFiber 1 & 72,4 & 1,9 & 19 & 6,7 & \multirow[t]{3}{*}{$\begin{array}{l}\text { Komposit } \\
\text { Sandwich }\end{array}$} \\
\hline & EVA Fiber 2 & 72,4 & 1,9 & 19 & 6,7 & \\
\hline & EVAFiber 3 & 72,4 & 1,9 & 19 & 6,7 & \\
\hline
\end{tabular}

Tabel 3. Komposisi Spesimen 
Pada proses pembuatannya spesimennya dilakukan dengan cara hand layout pada cetakan kaca persegi dengan ukuran $330 \mathrm{~mm} \times 330 \mathrm{~mm}$ dengan tebal $10 \mathrm{~mm}$. Pembuatan dimulai dengan menyiapkan bahan dan alat yang dibutuhkan. Setelah tersedia proses pembuatan dimulai dengan menyiapkan bahan-bahannya. Busa EVA dan Serat Kaca dipotong dengan ukuran $330 \mathrm{~mm} \times 330 \mathrm{~mm}$.

Kemudian timbang gelas plastik agar diketahui beratnya. Setelah itu dituangkan katalis dan resin BQTN 157 kedalam gelas plastik. Bahan-bahan campuran ditimbang agar diperoleh berat yang sesuai untuk spesimen. Sebelum bahan-bahan dituangkan kedalam cetakan kaca dioleskan glazing wax kepermukaan cetakannya untuk mempermudah melepaskan spesimen yang telah kering. Setelah glazing wax dioleskan dengan rata resin dan katalis diaduk sampai merata untuk mempercepat pengeringan.Campuran yang telah diaduk dituang kedalam cetakan hingga merata.Setelah campuran rata, bagian atas cetakan ditutup dengan lempengan kaca agar bagian atasnya merata dan diberi pemberat agar diperoleh tekanan.

Untuk spesimen GlassFibre Reinforced Polymer setelah cetakan dituang ke dalam cetakan ditaruh lapisan serat kaca satu persatu sambil diratakan.Setelah 5 lapisan serat kaca ditaruh dan campuran rata, cetakan ditutup dengan lempengan kaca dan diberi beban pemberat.

Untuk spesimen PolyesterPolymer sandwich EVA foam setelah campuran resin dan katalis yang didalam cetakan kaca mengental ditaruh lembaran Busa EVA diatasnya agar bisa menyatu. Setelah Busa EVA ditaruh lempengan kaca dan bebanuntuk memberikan tekanan pada Busa EVA agar ikatan antara resin dan Busa EVA rata.

Untuk spesimen Glass Fibre Reinforced Polymer sandwich EVA foam campuran Resin dan Katalis dituang kedalam cetakan diletakkan lapisan serat kaca hingga merata sebanyak 5 lapisan. Setelah itu ditaruh lapisan busa EVA diatasnya lalu diberi lempengan kaca dan beban.

Setelah spesimen dibiarkan selama 1-2 hari lempengan kaca dibuka, dan spesimen dilepaskan dari cetakan. Spesimen yang dibuat pada tiap jenismaterial dibuat sebanyak 3 spesimen. Spesimen yang dibuat, dipersiapkan untuk dilakukan pengujian jatuh bebas.

Pengujian impak jatuh bebas dilakukan untuk mendapatkan besarnya gaya impak dan tegangan akibat jatuh dari ketinggian $3 \mathrm{~m}$ yang dapat diterima spesimen pelindung dada. Pada pengujian ini digunakan pengujian impak benda jatuh bebas dengan asumsi bahwa pelindung dada pengendara sepeda motor menerima beban tekan dinamik

Pada penelitian ini digunakan beberapa peralatan yaitu alat uji impak jatuh bebas, dan alat pengukur energi dan gaya impak.

Alat pengukur energi dan gaya impak benda jatuh bebas (loadcell) adalah sebuah sensor gaya yang bekerja menggunakan strain gage full bridge dengan tahanan SG $350 \Omega$ alat yang dapat merekam beban impak seperti yang terlihat pada Gambar 3.20. Kemampuan alat ini dapat menerima beban dan mengukur gaya impak hingga $30.000 \mathrm{~kg}$, dan untuk penggunaan alat ini sudah mendapatkan sertifikat kalibrasi dari Komite Akreditasi Nasional untuk 20.000 kg [9].

\section{HASIL DAN PEMBAHASAN}

Pembebanan pada pengujian impak jatuh bebas diberikan pada bagian depan spesimen pelindung dada pengendara sepeda motorIni dikarenakan bagian tersebut merupakan bagian yang memiliki kemungkinan terbesar mengalami benturan.

Data hasil simulasi akan dibandingkan dengan hasil pengujian impak jatuh bebas. Pengujian impak jatuh bebas ini digolongkan pada pengujian impak kecepatan rendah.Alat uji impak jatuh bebas menggunakan sensor cahaya yang diletakkan dengan ketinggian $3 \mathrm{~m}$.

Alat yang digunakan untuk mengukur beban impak jatuh bebas menggunakan load cell. Data yang diperoleh load cell berupa data analog kemudian diubah oleh DAQ menjadi data digital. Kemudian data digital ditampilkan dan direkam oleh komputer. Data yang ditampilkan adalah data pengukuran gaya impak dan waktu impak. Kemudian data tersebut diolah agar dapat diperoleh tegangan yang terjadi. Data tegangan dapat dilihat pada tabel 4 untuk material Polyester Polymer, tabel 5 untuk material Polyester Polymer Sandwich EVA foam, tabel 6 untuk material Glass Fibre Reinforced Polymer (GFRP) dan tabel 7 untuk material Glass Fibre Reinforced Polymer (GFRP) Sandwich EVA foam.

Tabel 4. Hasil Uji Jatuh Bebas Material Polyester Polymer 


\begin{tabular}{cccc}
\hline Spesimen & $\begin{array}{c}\text { Luas Daerah } \\
\text { Impak A } \\
(\mathrm{m} 2)\end{array}$ & $\begin{array}{c}\text { Gaya } \\
\text { Maksimum } \\
\text { F(N) }\end{array}$ & $\begin{array}{c}\text { Tegangan } \sigma \\
(\mathrm{Mpa})\end{array}$ \\
\hline Resin 1 & 0,04906 & 539,05 & 0,011 \\
Resin 2 & 0,04906 & 627,45 & 0,012 \\
Resin 3 & 0,04906 & 556,81 & 0,011 \\
\hline
\end{tabular}

Tabel 5. Hasil Uji Jatuh Bebas Material Polyester Polymer Sandwich EVA foam

\begin{tabular}{cccc}
\hline Spesimen & $\begin{array}{c}\text { Luas Daerah } \\
\text { Impak A } \\
(\mathrm{m} 2)\end{array}$ & $\begin{array}{c}\text { Gaya } \\
\text { Maksimum } \\
\text { F(N) }\end{array}$ & $\begin{array}{c}\text { Tegangan o } \\
(\mathrm{Mpa})\end{array}$ \\
\hline EVAResin 1 & 0,04906 & 671,69 & 0,013 \\
EVA Resin 2 & 0,04906 & 636,27 & 0,013 \\
EVA Resin 3 & 0,04906 & 742,42 & 0,015 \\
\hline
\end{tabular}

Tabel 6. Hasil Uji Jatuh Bebas Material Glass Fibre Reinforced Polymer

\begin{tabular}{cccc}
\hline Spesimen & $\begin{array}{c}\text { Luas Daerah } \\
\text { Impak A } \\
(\mathrm{m} 2)\end{array}$ & $\begin{array}{c}\text { Gaya } \\
\text { Maksimum } \\
\mathrm{F}(\mathrm{N})\end{array}$ & $\begin{array}{c}\text { Tegangan } \sigma \\
(\mathrm{Mpa})\end{array}$ \\
\hline Fiber 1 & 0,04906 & 698,17 & 0,014 \\
Fiber 2 & 0,04906 & 556,81 & 0,011 \\
Fiber 3 & 0,04906 & 556,81 & 0,011 \\
\hline
\end{tabular}

Tabel 7. Hasil Uji Jatuh Bebas Material GFRP Sandwich EVA foam

\begin{tabular}{cccc}
\hline Spesimen & $\begin{array}{c}\text { Luas Daerah } \\
\text { Impak A } \\
(\mathrm{m} 2)\end{array}$ & $\begin{array}{c}\text { Gaya } \\
\text { Maksimum } \\
\mathrm{F}(\mathrm{N})\end{array}$ & $\begin{array}{c}\text { Tegangan } \sigma \\
(\mathrm{Mpa})\end{array}$ \\
\hline Fiber 1 & 0,04906 & 698,17 & 0,014 \\
Fiber 2 & 0,04906 & 556,81 & 0,011 \\
Fiber 3 & 0,04906 & 556,81 & 0,011 \\
\hline
\end{tabular}

Pengujian eksperimental tidak cukup untuk mengetahui kejadian impak yang terjadi secara spesimen secara menyeluruh, untuk itu digunakan simulasi software menganalisa secara lebih seksama. Setelah pengujian impak jatuh bebas telah diperoleh bahwa jenis komposit yang tidak ada perubahan fisik ketika menghantam anvil adalah spesimen yang bersatu dengan Glass Fibre Reinforced Polymer (GFRP). Untuk itu simulasi yang dilakukan adalah pada material Glass Fibre Reinforced Polymer karena Busa EVA digunakan sebagai lapisan pengikat ketika material terjadi perubahan fisik serta penambahan daya tahan material terhadap gaya gunting. Data dibawah ini merupakan hasil simulasi dari Analisis Komputasi Komposit pada Pelindung Dada Pengendara Sepeda Motor yang dilakukan oleh Gunawan Hartono yang ditunjukkan pada gambar 3.

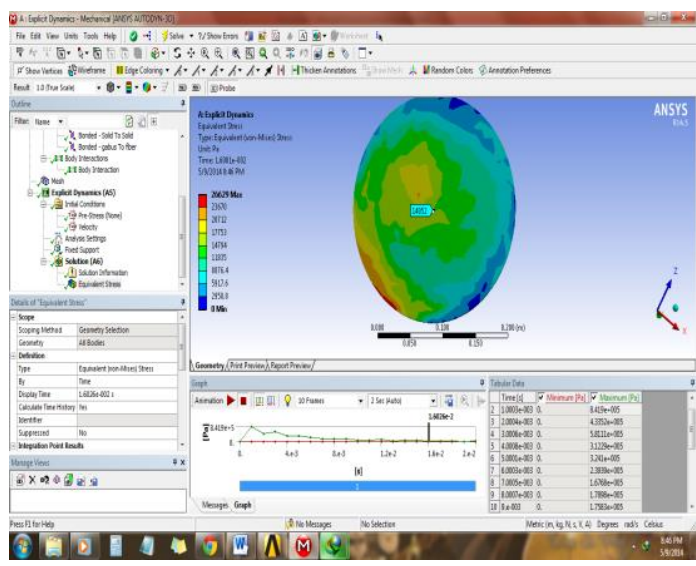

Gambar 3. Simulasi Impak pada spesimen GFRP pada waktu 16 ms 
Pada Gambar 3 ditunjukkan tegangan yang terjadi pada spesimen berupa 14952 Pa. Kejadian yang disimulasikan pada gambar 3 merupakan ketika waktu 16 ms karena waktu terjadi Gaya puncak yang terdeteksi ketika pengujian adalah pada waktu $16 \mathrm{~ms}$.

Data simulasi tersebut di bandingkan dengan data eksperimen untuk sebagai validasi data yang akan digunakan sebagai basis penentuan data.

$\%$ Galat $=\frac{14952-14231}{14952} * 100 \%=4,82 \%$

Setelah dilakukan perhitungan diperoleh galat antara pengujian eksperimental dengan simulasi computer berupa 4,82\%. Untuk itu data ini akan digunakan sebagai acuan atas gaya yang terjadi pada spesimen.

Pada Gambar 4 ditunjukkan bahwa tegangan maksimum yang terjadi pada waktu 1 ms dengan nilai $595550 \mathrm{~Pa}$. Dari tegangan tersebut dapat diperoleh bahwa Gaya Impak maksimum yang diterima spesimen adalah $29,18 \mathrm{kN}$.

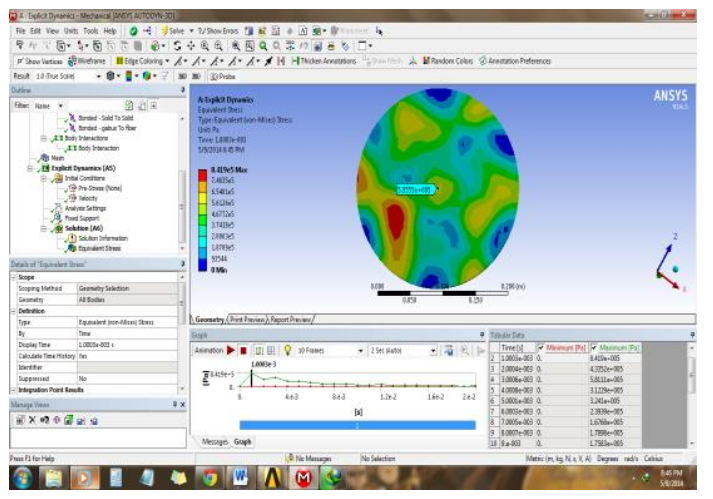

Gambar 4. Tegangan maksimum yang terjadi pada spesimen

Dari nilai tersebut kita akan mendapat tegangan rata-rata pada spesimen adalah $305251 \mathrm{~Pa}$ yang berarti menyimpan gaya sebesar $14,95 \mathrm{kN}$. Kemudian hasil tersebut dibandingkan dengan produk pelindung dada yang dijual di pasaran yaitu LEATT 5.50 yang terbuat dari bahan High Density Poly Ethylenedengan modulus elastisitas 0,8 Gpa dan densitas $970 \mathrm{~kg} / \mathrm{m}^{3}$. Perbandingan data antara spesimen dan pelindung dada LEATT dapat dilihat pada Tabel 6 berikut:

Tabel 8. Pembandingan Transmisi Gaya

\begin{tabular}{cccc}
\hline $\begin{array}{c}\text { Transmisi Gaya } \\
\text { Impak }\end{array}$ & $\begin{array}{c}\text { Standar } \\
\text { EN 1621-3 }\end{array}$ & $\begin{array}{c}\text { LEATT 5.50 } \\
\text { PRO LITE }\end{array}$ & Spesimen \\
\hline Rata-Rata(kN) & $<20$ & 12.1 & 14.95 \\
Maksimum (kN) & $<35$ & 22.7 & 29.18 \\
\hline
\end{tabular}

Dengan hasil pembandingan sifat material komposit sandwichyang telah diuji dan disimulasikan material komposit yang akan digunakan pada desain pelindung dada adalah material Glass Fibre Reinforced Polymer Sandwich EVA Foamyang disatukan dengan material busa EVA yang berbentuk jaket.

Pada Gambar 5 dapat terlihat hasil jadi dari pelindung dada yang telah digunakan. Pelindung dada tersebut terletak di bagian dada agar dapat mendispersikan gaya yang akan terjadi akibat tumbukan sehingga mengurangi tegangan yang terjadi pada dada pemakainya. 


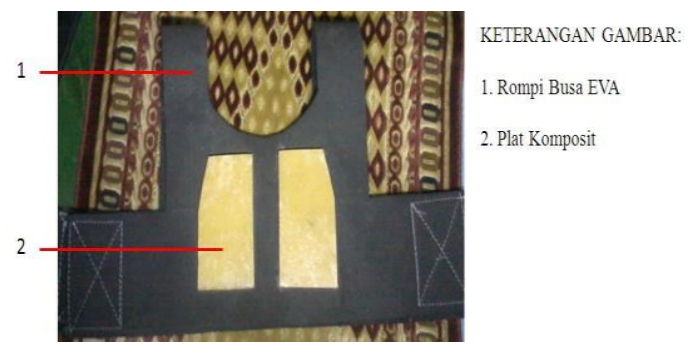

Gambar 5. Pelindung Dada

Pada pemasangan pelindung dada, kepala pemakai dimasukkan ke dalam lubang yang terdapat ditengah dan akan terlipat menyesuaikan badan. Bagian sisi bawah akan berfungsi sebagai sisi pengikat variabel agar dapat diatur keketatannya. Bagian dada dilindungi dengan material GFRP yang bersifat tangguh agar dapat menerima gaya impak yang terjadi ketika terjadi kecelakaan. Bagian dada dibuat miring pada sisi atas agar tidak mengganggu pergerakan tangan. Bagian lainnya dibuat dari Busa EVA yang elastis agar mudah untuk dilipat atau disimpan.

\section{KESIMPULAN}

1. a. Dari hasil pengujian jatuh bebas pada material Polyester Polymer diketahui bahwa material ini tidak mampu menerima gaya impaksebesar 627,45 $\mathrm{N}$ dan tegangan sebesar 0,012 MPa sehingga tidak cocok digunakan sebagai material pelindung dada.

b. Dari hasil pengujian jatuh bebas pada material PolyesterPolymer Sandwich EVA Foam diketahui bahwa material ini masih berbentuk utuh ketika menerima gaya impaksebesar 742,42 N dan tegangan sebesar 0,015 MPa tetapi terjadi keretakan pada spesimen sehingga terdapat risiko material yang retak tersebut dapat menusuk pemakainya.

c. Dari hasil pengujian jatuh bebas pada material Glass Fibre Reinforced Polymer diketahui bahwa material ini masih berbentuk utuh ketika menerima gaya impak sebesar 698,17 Ndan tegangan sebesar 0,014 MPa tetapi untuk menyatukan bahan ini ke busa EVA dapat menyebabkan penyusutan dan pemadatan pada rompi busa EVA.

d. Dari hasil pengujian jatuh bebas pada materialGlass Fibre Reinforced Polymer Sandwich EVA Foam diketahui bahwa material ini tidak terjadi perubahan bentuk ketika menerima gaya impak sebesar 769,79 $\mathrm{N}$ dan tegangan sebesar 0,015 MPa. Bagian bawah plat komposit ini terdiri dari busa EVA sehingga mudah disatukan dengan rompi busa EVA.

2. Perbandingan data eksperimental dengan komputasi memiliki galat sebesar $4,82 \%$

3. Dari hasil uji eksperimental dan komputasididesain produk ini dengan spesifikasi Glass Fibre Reinforced Polymer Sandwich EVA Foam dengann kemampuan menahan gaya impak sebesar $769,79 \mathrm{~N}$. Bentuk plat komposit dibuat trapesium agar memudahkan gerakan lengan pemakainya yang posisi penyatuannya terletak di bagian tulang rusuk.Pelindung dada juga dapat di atur ukurannya karena menggunakan perekat velcro.

\section{REFERENSI}

[1] Chawla,A., Mukherjee,S., Mohan, D.,Bose, Bose,D.,Rawat,P. 2001. FE Simulations of Motorcycle - Car Frontal Crashes, Validaton and Observations. Indian Institute of Technology. http://tripp.iitd.ernet.in/publications/paper/biomech/18ESV-FEsimul.pdf diakses tgl 03-102013 jam 11:00 WIB

[2] Spesifikasi produk Chest Protector LEATT PRO LITE. http://www.leattbrace.com/product_uploads/ce_certificates/CHEST\%20PROTECTOR\%20LEATT\%205.5\%20 PRO\%20LITE.pdf diakses tgl 13-05-2014 jam 13:00 WIB

[3] http://www.highvelocitygear.com/ diakses tgl 13-05-2014 jam 13:10 WIB

[4] Chawla, K.K. 1987. Composite materials, First Ed.Berlin: Springer-Verlag New York Inc.

[5] http://www.satra.co.uk/spotlight/article_view.php?id=190 diakses tgl 14-05-2014 jam 14:30 WIB 
[6] Glass Fibre Reinforced Product for Industrial Applications. Amitech Industrial.http://www.amiantit.com/media/pdf/brochures/Glass_Fibre_Reinforced_Products/ files/Glass_Fibre_Reinforced_Products.pdf diakses tgl 14-05-2014 jam 15:15

[7] Material Data Book.2003. Cambridge University Engineering Departement. http://wwwmdp.eng.cam.ac.uk/web/library/enginfo/ cueddatabooks/materials.pdf diakses tgl 14-05-2014 jam 15:10

[8] Robert, M. 2007. Impact and Drop Testing with ICP Force Sensors. PCB Piezotronics, Inc., Depew, New York. http://www.sandv.com/downloads/0702metz.pdf diakses tanggal 26 Juni 2014 jam 16:34 WIB

[9] Simanjuntak, Rahmat Kartolo. Pengukuran Helmet Sepeda Motor Yang Dikenai Beban Impak Menggunakan Metode Jatuh Bebas. Repository USU. 21 Maret 2012. http://repository.usu.ac.id/handle/123456789/31946diakses tgl 30-10-2013 jam 13:24 WIB 